\title{
Pancreatic cystic echinococcosis causing acute pancreatitis
}

\author{
(1) Sabahattin Destek, M.D., ${ }^{1}$ ㄴ) Kamuran Cumhur Değer, M.D. ${ }^{2}$
}

\begin{abstract}
'Department of General Surgery, Sancaktepe Şehit Prof. Dr. İlhan Varank Training and Research Hospital, İstanbul-Turkey
${ }^{2}$ Department of General Surgery, Bezmialem Vakıf University Faculty of Medicine, İstanbul-Turkey
\end{abstract}

\begin{abstract}
Echinococcosis is a zoonotic infestation, most commonly arises from Echinococcus granulosus helminth. The definitive hosts are carnivora, such as dogs and cats, and the intermediate hosts are herbivores, including cattle, sheep and goats. Humans are intermediate hosts, causing cystic echinococcosis. In our country, the incidence of echinococcos is $14 \%$. The disease is localized in the liver by $70 \%$. Cyst hydatid localized in the pancreas is unusual, with an incidence of $0.2-0.6 \%$, and rarely causes acute pancreatitis. In this report, we present a 45 -year-old male patient with cyst hydatid, which manifested by an acute pancreatitis attack. In the examination, there was a CE2 type according to WHO classification stage III cyst hydatid of $97 \mathrm{~mm}$ diameter with septa associated with Wirsung duct, acute pancreatitis and splenomegaly. The indirect hemagglutination test was >I: 2560 . The patient underwent pancreatectomy and splenectomy following medical therapy with Albendazole tablet for four weeks. IHA of the patient was found as I/32 in the third month. Cyst hydatid should be considered in the differential diagnosis of all cystic masses, especially in the regions where the disease is endemic. In addition, it should be remembered that although rarely seen, pancreatic cyst hydatid may cause acute pancreatitis.
\end{abstract}

Keywords: Acute pancreatitis; Echinococcus granulosus; pancreatic cystic echinococcosis.

\section{INTRODUCTION}

Echinococcus, a tropical disease, affects more than I million people worldwide. ${ }^{[1]}$ The definitive hosts for adult Echinococcus cestodes are carnivore, such as dogs, foxes, and cats, while the intermediate hosts for larva metacestodes are herbivores, including sheep, goats, and cattle. ${ }^{[1,2]}$ Humans are incidental intermediate hosts. ${ }^{[1,2]}$ Echinococcosis is localized in the liver by $70 \%$ and lungs by $20 \% .^{[2,3]}$ Causative agent of echinococcus is E. granulosus by $90 \% .{ }^{[4]}$ The disease is endemic in South America, the Middle East, Central Asia, East Africa and Australia. ${ }^{[3,4]}$ Its incidence is $50 / 100.000$ per year and prevalence is $5 \%$ to $10 \% .{ }^{[4,5]}$ In our country, the incidence has been reported as 6.3/100.000 annually, and the prevalence as $14 \% .^{[5]}$

Pancreatic cystic echinococcosis (PCE) is an unusual localization of involvement with a prevalence of $0.2-0.6 \%{ }^{[6,7]} \mathrm{PCE}$ may cause recurrent acute pancreatitis by compression or fistulization to the pancreatic duct and obstructive jaundice. ${ }^{[8-10]}$ In this report, we presented a 45 -year-old male patient who was examined due to an acute pancreatitis attack and treated with the diagnosis of PCE. The patient's consent was obtained for the case report.

\section{CASE REPORT}

Physical examination of a 45-year-old male patient who presented with the complaints of abdominal pain, nausea, vomiting and fever, revealed tenderness in the epigastric area, abdominal distension, $38.7^{\circ} \mathrm{C}$ fever, and a palpable abdominal mass in the left upper quadrant. The body mass index of the patient was $29.8 \mathrm{~kg} / \mathrm{m}^{2}$. In the blood tests, there were increases in leukocyte (I7.500 uL), C reactive protein (CRP) (57 mg/L), liver function tests (AST $273 \mathrm{U} / \mathrm{L}$ ALT $312 \mathrm{U} / \mathrm{L}$, LDH $440 \mathrm{U} / \mathrm{L}, \mathrm{GGT} 120 \mathrm{U} / \mathrm{L})$, amylase (2I43 U/L) and lipase (586 U/L).

Cite this article as: Destek S, Değer KC. Pancreatic cystic Echinococcosis causing acute pancreatitis. Ulus Travma Acil Cerrahi Derg 2020;26:951-954.

Address for correspondence: Sabahattin Destek, M.D.

Sancaktepe Şehit Prof. Dr. İlhan Varank Egitim ve Araştırma Hastanesi, Genel Cerrahi Kliniği, 34785 İstanbul, Turkey

Tel: +90 216 - 6063300 E-mail: sebahattindestek@yahoo.com

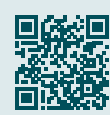

Ulus Travma Acil Cerrahi Derg 2020;26(6):95I-954 DOI: 10.14744/tjtes.2019.85069 Submitted: 25.05.20I9 Accepted: II.II.2019 Online: 27.10.2020

Copyright 2020 Turkish Association of Trauma and Emergency Surgery 
On the tomography ordered, a cyst hydatid of $97 \times 85 \times 74 \mathrm{~mm}$ in the corpus-tail section of the pancreas, acute edematous interstitial pancreatitis and splenomegaly were found. PCE and duct of Wirsung seemed associated. Varicose venous structures were found in the splenic hilus and omentum due to the splenic vein compression by PCE. On magnetic resonance imaging (MRI), PCE was seen to be associated with the duct of Wirsung. PCE was compatible with World Health Organization Informal Working Group on Echinococcosis (WHO-IWGE) CE2 type according to the radiological features. Echinococcosis was not found in the regions out of the pancreas (Fig. I). Indirect hemagglutination test (IHA) result was high (>I:283I) (ref: <I:I60). The patient was hospitalized and administered early enteral feeding, pain therapy and fluid replacement, and albendazole was initiated as $15 \mathrm{mg} / \mathrm{kg} /$ day with the diagnosis of Ranson III acute pancreatitis and PCE. He was discharged after one week. Albendazole was continued for one month. In the control tests, leukocyte,
CRP, amylase, lipase and liver function tests were returned to normal. IHA was found as $>1$ : 1847 .

The patient was decided to undergo surgery. In the laparoscopic exploration, left-sided (sinistral) portal hypertension findings due to PCE compression, such as distinct varicose veins in the splenic vein, gastrica breves and omentum, were detected. Since the PCE was large and very adherent to the surrounding tissues, open surgery was performed. Distal pancreatectomy and splenectomy were performed in the patient to involve PCE. Germinative membrane and hydatid sand structures were detected in the duct of Wirsung during resection of the pancreas. The duct of Wirsung was washed and cleaned with a physiological saline solution. The duct of Wirsung was sutured. The piece was taken out of the abdomen (Fig. 2).

The patient was discharged on the postoperative $8^{\text {th }}$ day. In the histopathological examination, echinococcosis was $10 \times 7$
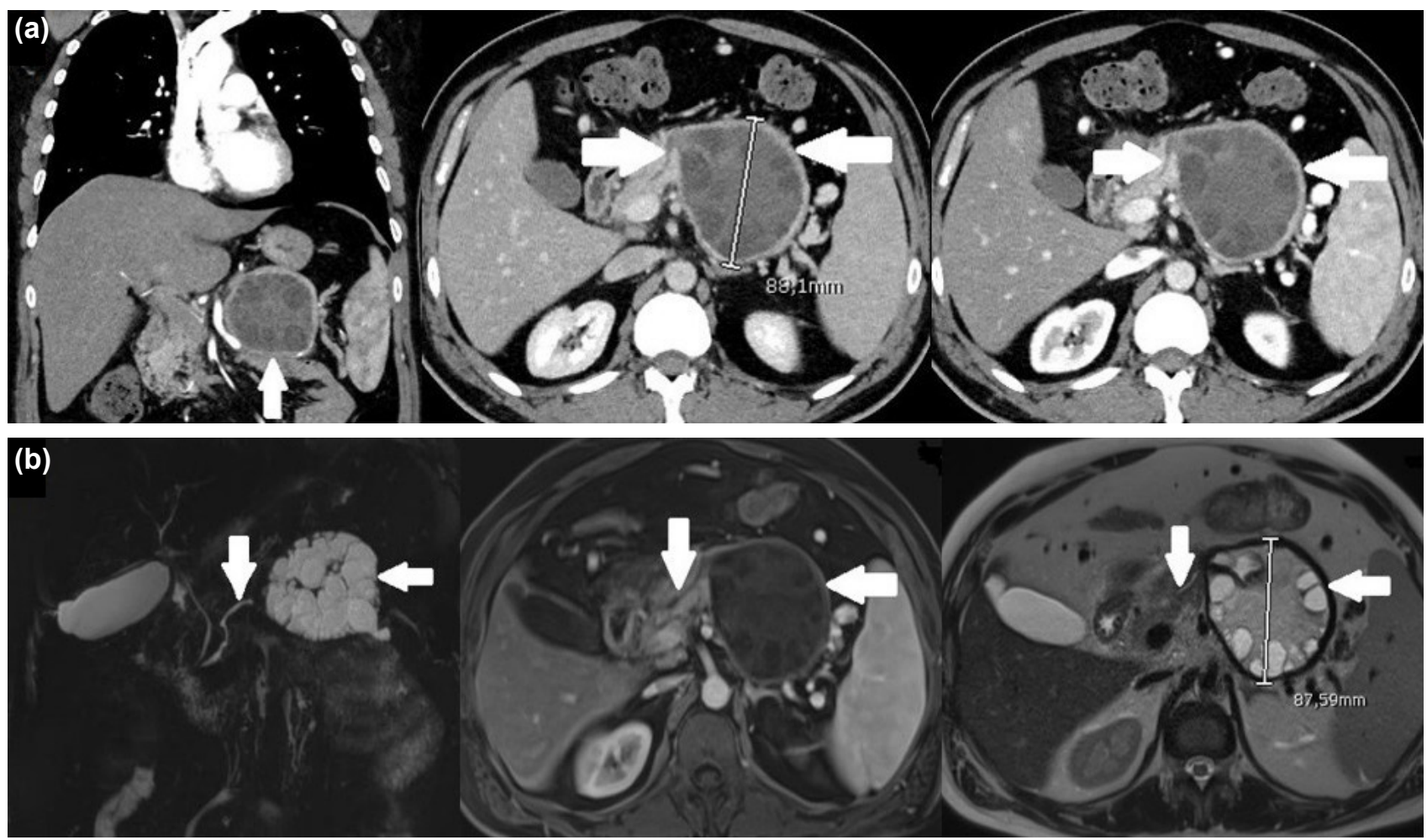

Figure 1. Pancreatic echinococcosis. (a) Computed tomography image showing an Echinococcus granulosus cyst containing daughter cysts within the pancreas. (b) Coronal T2 magnetic resonance cholangiopancreatography of the cyst - pancreatic fistula, Axial T1 and T2 magnetic resonance image showing an Echinococcus granulosus cyst containing daughter cysts within the pancreas.

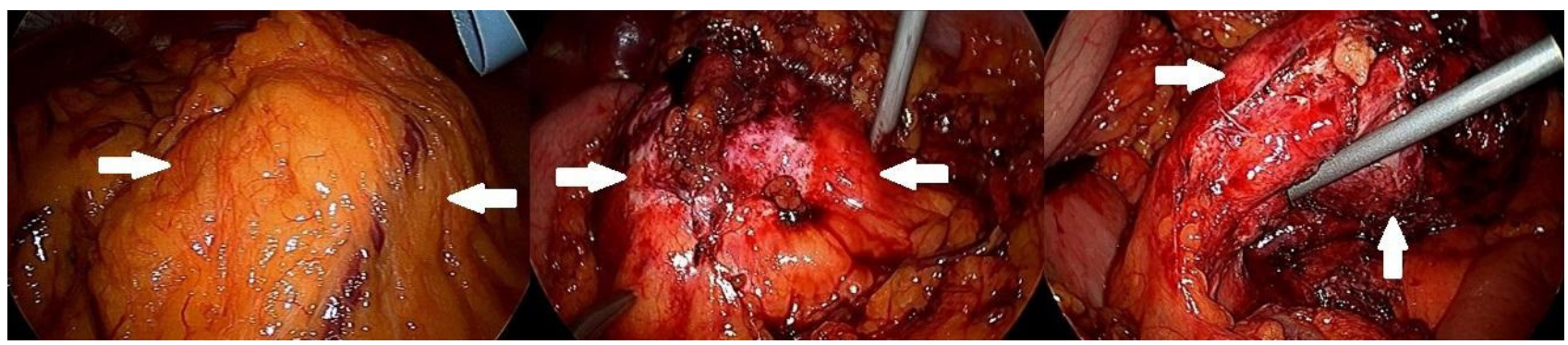

Figure 2. Pancreatic cystic echinococcosis in the operation. 
$\mathrm{cm}$ in size, and numerous scolex and germinative membrane were detected. Albendazole at a dose of $15 \mathrm{mg} / \mathrm{kg} /$ day was continued for postoperative three months. No problem was detected on the control tomography performed in the postoperative $3^{\text {rd }}$ month. IHA of the patient was negative in the $3^{\text {rd }}$ month. Patient consent was obtained for this study.

\section{DISCUSSION}

Echinococcosis is frequently seen in the regions where agriculture and stock raising are widespread. ${ }^{[1]}$ Pathogenic CE species in humans are E. granulosus sensu stricto (GI-G3), E. equinus (G4), E. ortleppi (G5) and E. canadensis (G6-G I0). The causative agent in $C E$ is $E$. granulosussensu stricto $G$ I genotype by $88 \%{ }^{[1,2,4]}$ These agents cause cystic echinococcosis (CE) consisting of protoscoleces and daughter vesicles. ${ }^{[2]}$ Ten percent of CE may develop in an unusual localization, such as the spleen $(6 \%)$, kidneys $(2 \%)$, and brain $(2 \%){ }^{[1,12]}$

The incidence of PCE is lower than $2 \% .^{[10,11]}$ The embryos reach the pancreas most commonly through the hematogenous spread, local spread from the biliary system, lymphatic passage from the intestinal mucosa and retroperitoneal spread. ${ }^{[7, I I]} P C E$ is usually seen in men and in the $3^{\text {rd }}-4^{\text {th }}$ decades of life. ${ }^{[9,1]}$ PCE may occur as primary (isolated pancreas) or secondary (multiple organs). ${ }^{[10,11]}$ Of all the PCE cases, $28 \%$ are primary. ${ }^{[1]}$ In published studies, $90 \%$ of PCEs are solitary, with $50 \%$ are found in the head, $34 \%$ in the corpus, and $16 \%$ in the tail of the pancreas. ${ }^{[1-13]}$ The diameter of PCE may vary between 26 and $180 \mathrm{~mm} .^{\left[{ }^{[1]}\right.}$ Our case was a 45-year-old male patient with a primary, solitary PCE in the body-corpus section of the pancreas with a diameter of $97 \mathrm{~mm}$.

The clinical picture depends on the localization of PCE in the pancreas. ${ }^{[9-11]}$ The main symptoms include pain in the epigastric region (69\%) or left upper quadrant (31\%), jaundice (26\%), nausea-vomiting (16\%) and fever (8\%). ${ }^{[7,11]}$ The main complications are pancreatitis (15\%), sinistral portal hypertension (12.5\%), cholangitis, duodenal stenosis and duodenal fistula. ${ }^{[8,11,13]}$ In our patient, the most significant complaint was upper abdominal pain, while pancreatitis and sinistral portal hypertension were found together with PCE.

When receiving medical history, living in endemic regions should be considered. ${ }^{\left[{ }^{\prime \prime}\right]}$ Ultrasonography is a noninvasive and low-cost method; however, its sensitivity is low since the pancreas is localized retroperitoneally. ${ }^{[6,11]}$ Tomography is successful in the determination of the size and localization of PCE, its association with the pancreato-biliary system, and detection of postoperative recurrence. ${ }^{[10,11]} \mathrm{MRI}$ is useful in the identification of the fistulas between PCE and pancreas and biliary ducts. Endoscopic ultrasonography can be performed to determine the fistulas between PCE and pancreas and biliary ducts, and to perform a biopsy. ${ }^{[1,14]}$ Endoscopic retrograde cholangiopancreatography can be performed to apply stenting in biliopancreatic obstruction and fistulas. ${ }^{[10,12]}$
Radiologically, WHO-IWGE classifications are used in the grading of CE. ${ }^{[6,14]}$ In our study, PCE was compatible with CE2 type according to WHO-IWGE classification.

Several tests, such as enzyme-linked immunosorbent assay (ELISA), indirect hemagglutination, serum immunoelectrophoresis, complement fixation and immunofluorescence assays, are used for diagnosis, screening and follow up. ${ }^{[2,12]}$ The seropositivity rate in PCE is approximately $54 \%{ }^{[11,10]}$ On the other hand, seronegativity does not rule out echinococcosis. ${ }^{[1,2]}$ In our patient, the IHA test was positive.

Differential diagnosis of PCE includes pancreas cystadenoma, cystadenocarcinoma, cystic metastatic lesions, congenital pancreas cysts and pseudocysts. ${ }^{[7, I I]}$ Fine needle aspiration biopsy or cyst fluid aspiration cytology with percutaneous or endoscopic ultrasonography can be performed in patients in whom diagnosis cannot be established. ${ }^{[6,7]}$ In our patient, a biopsy was not needed.

Patients' age, comorbidity, localization and size of the cyst, and its association with the pancreatobiliary system are considered in the selection of a treatment option for PCE. ${ }^{[6,8]}$ Minimal invasive approaches, such as medical therapy, percutaneous catheterization or PAIR (Puncture-aspiration-injection-respiration), and open or laparoscopic surgical methods, are used alone or in combination. ${ }^{[8,12]}$

Partial cystectomy, pericystectomy, distal pancreatectomy and pancreaticoduodenectomy may be performed. ${ }^{[6,8,15]}$ Splenectomy may also be added in the case of splenic vein invasion or occlusion. ${ }^{[9,13]}$ To reduce the risk of anaphylaxis and recurrence, prophylactic treatment (albendazole, mebendazole, praziquentel) should be administered in the pre- and postoperative periods before and after surgery for three to four weeks. ${ }^{[12,15]}$ Postoperative early complications include pancreatic fistulas, biliary fistulas, biloma, intraabdominal abscess and wound infection. ${ }^{[8,11]}$ The late complication is a recurrence of echinococcosis. ${ }^{[6,7]}$ We also administered prophylactic medical therapy in our patient. The patient who underwent distal pancreatectomy and splenectomy did not develop postoperative complications.

In conclusion, PCE is a rare parasitic infestation, which may cause serious pancreatobiliary complications. It should be remembered in the differential diagnosis of pancreatic cysts in endemic areas.

Informed Consent: Written informed consent was obtained from the patient for the publication of the case report and the accompanying images.

Peer-review: Internally peer-reviewed.

Conflict of Interest: None declared.

Financial Disclosure: The authors declared that this study 


\section{has received no financial support.}

\section{REFERENCES}

1. Agudelo Higuita NI, Brunetti E, McCloskey C. Cystic Echinococcosis. J Clin Microbiol 2016;54:518-23. [CrossRef]

2. Moro P, Schantz PM. Echinococcosis: a review. Int J Infect Dis 2009;13:125-33. [CrossRef]

3. Alvarez Rojas CA, Romig T, Lightowlers MW. Echinococcus granulosus sensu lato genotypes infecting humans--review of current knowledge. Int J Parasitol 2014;44:9-18. [CrossRef]

4. Yazar S, Ozkan AT, Hökelek M, Polat E, Yilmaz H, Ozbilge H, et al. Cystic echinococcosis in Turkey from 2001-2005. [Article in Turkish]. Turkiye Parazitol Derg 2008;32:208-20.

5. Sayır F, Çobanoğlu U. A parasitic disease which is endemic in our region: Hydatid cyst. Van Med J 2013;20:288-93.

6. Dziri C, Dougaz W, Bouasker I. Surgery of the pancreatic cystic echinococcosis: systematic review. Transl Gastroenterol Hepatol 2017;2:105.

7. Bayat AM, Azhough R, Hashemzadeh S, Barband A, Yaghoubi AR, Gargari RM. Hydatid cyst of pancreas presented as a pancreatic pseudocyst. Am J Gastroenterol 2009;104:1324-6. [CrossRef]

8. Alsaid B, Alhimyar M, Rayya F. Pancreatic Hydatid Cyst Causing Acute
Pancreatitis: A Case Report and Literature Review. Case Rep Surg 2018;2018:9821403. [CrossRef]

9. Ozsay O, Gungor F, Karaisli S, Kokulu I, Dilek ON. Hydatid cyst of the pancreas causing both acute pancreatitis and splenic vein thrombosis. Ann R Coll Surg Engl 2018;100:e178-80. [CrossRef]

10. Akbulut S, Yavuz R, Sogutcu N, Kaya B, Hatipoglu S, Senol A, et al. Hydatid cyst of the pancreas: Report of an undiagnosed case of pancreatic hydatid cyst and brief literature review. World J Gastrointest Surg 2014;6:190-200. [CrossRef]

11. Ahmed Z, Chhabra S, Massey A, Vij V, Yadav R, Bugalia R, et al. Primary hydatid cyst of pancreas: Case report and review of literature. Int J Surg Case Rep 2016;27:74-7. [CrossRef]

12. Dziri C, Haouet K, Fingerhut A. Treatment of hydatid cyst of the liver: where is the evidence?. World J Surg 2004;28:731-6. [CrossRef]

13. Canbak T, Acar A, Kıvanç AE, Bașak F, Kulalı F, Baș G. Sinistral Portal Hypertension Due to Pancreatic Hydatid Cyst. Türkiye Parazitol Derg 2017;41:226-8. [CrossRef]

14. Stojkovic M, Rosenberger K, Kauczor HU, Junghanss T, Hosch W. Diagnosing and staging of cystic echinococcosis: how do CT and MRI perform in comparison to ultrasound?. PLoS Negl Trop Dis 2012;6:e1880.

15. Trigui A, Rejab H, Guirat A, Mizouni A, Ben Amar M, Mzali R, et al. Hydatid cyst of the pancreas. About 12 cases. Ann Ital Chir 2013;84:165-70

\section{OLGU SUNUMU - ÖZET}

\section{Akut pankreatite neden olan pankreas kistik ekinokokkozisi Dr. Sabahattin Destek, ${ }^{1}$ Dr. Kamuran Cumhur Değer ${ }^{2}$}

${ }^{1}$ Sancaktepe Sehit Prof. Dr. İlhan Varank Egitim ve Araştırma Hastanesi, Genel Cerrahi Kliniği, İstanbul ${ }^{2}$ Bezmialem Vakıf Universitesi Tıp Fakültesi, Genel Cerrahi Anabilim Dalı, İstanbul

Ekinokokkosiz, genellikle Echinococcus granulosus helmintinin neden olduğu zoonotik bir enfestasyondur. Köpek ve kedi gibi etoburlar kesin konakçı iken sığır, koyun keçi gibi otoburlar ara konakçıdırlar. İnsanlar ara konakçı olup onlarda kistik ekinokokkosize neden olurlar. Ülkemizde insidansı \%।4'dür. Hastalık \%70 oranında karaciğerde yerleşir. Kist hidatiğin pankreasa yerleşmesi sıra dışı olup \%0.2-0.6 oranında rastlanır ve nadiren akut pankreatite neden olur. Bu sunumda, akut pankreatit atağı ile kendini gösteren pankreas kist hidatiği saptanılan 45 yaşında bir erkek olgu sunuldu. Incelemelerinde pankreas gövde-kuyruk bölgesinde $97 \mathrm{~mm}$ çapında wirsung kanalı ile iştirakli, WHO sınıflandırmasına göre CE2 tipinde evre III kist hidatik, akut pankreatit ve splenomegali saptandı. İndirekt hemaglütinasyon testi > I: 2560 idi. Albendazol tablet ile dört hafta tıbbi tedavi sonrasında hastaya distal pankreatektomi ve splenektomi yapıldı. Hastanın üçüncü ayında IHA sonucu I/32 olarak bulundu. Özellikle hastalığın endemik olduğu coğrafi bölgelerde, pankreastaki tüm kistik kitlelerin ayırıı tanısında kist hidatik göz önünde bulundurulmalıdır. Ayrıca pankeas kist hidatiğinin nadir görülmesine rağmen akut pankreatite neden olabileceği akla getirilmelidir.

Anahtar sözcükler: Akut pankreatit; Echinococcus granulosus; pankreas kistik ekinokokkozisi.

Ulus Travma Acil Cerrahi Derg 2020;26(6):951-954 doi: 10.14744/tjtes.2019.85069 